\title{
New and paradoxical roles of matrix metalloproteinases in the tumor microenvironment
}

\section{Agnès Noël ${ }^{1}{ }^{*}$, Ana Gutiérrez-Fernández ${ }^{2}$, Nor Eddine Sounni ${ }^{1}$, Niels Behrendt ${ }^{3,4}$, Erik Maquoi ${ }^{1}$, Ida K. Lund ${ }^{3,4}$, Santiago Cal' ${ }^{2}$, Gunilla Hoyer-Hansen ${ }^{3,4}$ and Carlos López-Otín ${ }^{2}$}

${ }^{1}$ Laboratory of Tumor and Development Biology, GIGA-Cancer, University of Liège, Liège, Belgium

2 Departamento de Bioquímica y Biología Molecular, Instituto Universitario de Oncología, Universidad de Oviedo, Oviedo, Asturias, Spain

${ }^{3}$ The Finsen Laboratory, Copenhagen University Hospital, Copenhagen Biocenter, Copenhagen N, Denmark

${ }^{4}$ Biotech Research \& Innovation Centre, University of Copenhagen, Copenhagen Biocenter, Copenhagen N, Denmark

\section{Edited by:}

Pierre Sonveaux, University of Louvain Medical School, Belgium

Reviewed by:

Juan lovanna, INSERM, France Hervé Emonard, CNRS, France

Cyril Rauch, Nottingham University, UK

\section{${ }^{*}$ Correspondence:}

Agnès Noël, University of Liège, Laboratory of Tumour \& Development Biology, Tour de Pathologie, B23, Sart Tilman, B-4000 Liège, Belgium. e-mail: agnes.noel@ulg.ac.be
Processes such as cell proliferation, angiogenesis, apoptosis, or invasion are strongly influenced by the surrounding microenvironment of the tumor. Therefore, the ability to change these surroundings represents an important property through which tumor cells are able to acquire specific functions necessary for tumor growth and dissemination. Matrix metalloproteinases (MMPs) constitute key players in this process, allowing tumor cells to modify the extracellular matrix (ECM) and release cytokines, growth factors, and other cell-surface molecules, ultimately facilitating protease-dependent tumor progression. Remodeling of the ECM by collagenolytic enzymes such as MMP1, MMP8, MMP13, or the membranebound MT1-MMP as well as by other membrane-anchored proteases is required for invasion and recruitment of novel blood vessels. However, the multiple roles of the MMPs do not all fit into a simple pattern. Despite the pro-tumorigenic function of certain metalloproteinases, recent studies have shown that other members of these families, such as MMP8 or MMP11, have a protective role against tumor growth and metastasis in animal models. These studies have been further expanded by large-scale genomic analysis, revealing that the genes encoding metalloproteinases, such as MMP8, MMP27, ADAM7, and ADAM29, are recurrently mutated in specific tumors, while several ADAMTSs are epigenetically silenced in different cancers. The importance of these proteases in modifying the tumor microenvironment highlights the need for a deeper understanding of how stroma cells and the ECM can modulate tumor progression.

Keywords: matrix metalloproteinases, ADAM, cancer, tumor, microenvironment

\section{INTRODUCTION}

Genetic alterations in tumor cells are essential for tumor development but not sufficient to generate malignant tumors. The tumor stroma resulting from an evolving crosstalk between tumor cells and different host cell types is required to create a permissive environment for the invasion of genetically altered tumor cells (Hanahan and Weinberg, 2011; Lu et al., 2012). Key modifications of the stromal environment include enhanced vascularization following an "angiogenic switch" (Bergers et al., 2000), quantitative and qualitative changes in the extracellular matrix (ECM), and the recruitment of resident fibroblastic cells (Kalluri and Zeisberg, 2006), bone marrow-derived mesenchymal stem cells (Spaeth et al., 2009) and inflammatory cells (Coussens and Werb, 2001). The importance of the tumor microenvironment is now recognized as fundamental for cancer progression (Joyce and Pollard, 2009), but the critical molecular changes occurring in the tumor stroma accompanying and affecting cancer evolution remain largely unknown. Desmoplasia, the fibrotic stromal reaction associated with most carcinomas, is characterized by the local deposition of fibrillar collagen types I, III, and V. This host reaction correlating with adverse prognosis in mammary carcinomas (Hasebe et al., 2002) is also seen in metastatic sites (Erler and
Weaver, 2009). Remarkably, increased expression of interstitial collagen and many of its remodeling enzymes is frequently detected in gene signatures associated with poor prognosis in cancer patients (Ramaswamy et al., 2003; Finak et al., 2008; Tavazoie et al., 2008). In addition to quantitative changes in collagen deposition, the architecture of the collagen scaffold is also drastically affected during cancer evolution. In this context, collagen crosslinking by lysyl oxidase (LOX) whose expression is increased upon hypoxic conditions has emerged as a key determinant of late stage tumors (Erler et al., 2009).

It is now recognized that proteinases contribute actively to the elaboration of the stromal microenvironment during early and late stages of primary and secondary tumor development (Holmbeck et al., 2003; Noel et al., 2008). The degradation of collagen by cathepsins and matrix metalloproteinases (MMPs), and the receptor-mediated endocytosis of degraded collagen are important events that regulate cancer cell survival, growth, migration, and invasion. Proteinases act not only by disrupting physiological barriers to ease cell migration, but importantly by releasing growth and chemotactic factors from the ECM and unmasking cryptic domains of matrix components (Lopez-Otin and Overall, 2002; Kalluri, 2003). In addition, these enzymes are key regulators of 
shedding, activation, and/or degradation of cell-surface molecules including adhesion molecules, mediators of apoptosis, receptors of chemokines/cytokines, and intercellular junction proteins (Overall and Kleifeld, 2006; Cauwe et al., 2007; Lopez-Otin and Hunter, 2010).

In this review, we focus on secreted metalloproteinases (MMPs and disintegrin-metalloproteinases with thrombospondin domains, referred to as ADAMTSs) and the associated cell-surface receptor (uPARAP/endo180) specifically involved in interstitial collagen remodeling. We also describe novel findings generated by the collaborative EU-FP7 funded network, MicroEnviMet (No. HEALTH-F2-2008-201279). This project has shed light on novel functions of membrane-associated MMPs in the control of cell apoptosis and angiogenesis, as well as on the complex tumor-host interplay in which proteinases can either boost cancer progression or protect the host against malignancy.

\section{MMPS AND RELATED ENZYMES}

It is now recognized that proteinases contribute to all stages of tumor progression (growth, angiogenesis, invasion, and evasion to immune system) and are produced not only by the tumor cells themselves, but mainly by the different non-malignant host cells composing the tumor. Among the different classes of proteinases implicated during different stages of cancer progression, the MMPs constitute a family of 24 human zinc-binding endopeptidases that can degrade virtually all ECM components and have a growing number of substrates belonging to all important families of cell regulators: integrins, cell-surface receptors, kinases, chemokines, and cytokines (Egeblad and Werb, 2002; Lopez-Otin and Overall, 2002; Folgueras et al., 2004; Overall and Kleifeld, 2006;
Cauwe et al., 2007; Lopez-Otin and Hunter, 2010). Most MMPs are secreted as soluble enzymes but six of them are membrane-type MMPs (MT-MMPs) that are associated with the cell membrane by either a $\mathrm{COOH}$-terminal transmembrane domain (MT1-, MT2-, MT3-, MT5-MMP) or a glycosylphosphatidyl-inositol (GPI) anchor (MT4- and MT6-MMP). For a description of the structure, function, and regulation of MMPs and MT-MMPs, the reader is referred to previous reviews (Zucker et al., 2003; Sounni and Noel, 2005; Page-McCaw et al., 2007; Sohail et al., 2008; Fanjul-Fernandez et al., 2010; Kessenbrock et al., 2010; Strongin, 2010). The ADAMs are membrane-anchored proteinases that share the catalytic domain with the MMPs but which include two main differences: (1) the absence of a hemopexin-like domain and (2) the insertion of three additional domains [cysteine-rich domain, epidermal growth factor (EGF)-like domain and the disintegrin domain; Figure 1; Klein and Bischoff, 2011]. The related ADAMTS family contains 19 human metalloproteinases with a variable number of type-1 thrombospondin (TSP-1) domains in their C-terminal region. ADAMTSs are now viewed as key regulators of collagen maturation (ADAMTS-2, -3, and -14; Colige et al., 2005; Dubail et al., 2010), cartilage degradation (ADAMTS-1, -4, 5, -8, and -9), microfibril biogenesis (Hubmacher and Apte, 2011), von Willebrand factor maturation (ADAMTS-13), reproduction (ADAMTS-9, -20; Llamazares et al., 2007), and cancer progression (Handsley and Edwards, 2005; Rocks et al., 2008).

\section{COLLAGEN REMODELING}

The fibrillar collagens (e.g., types I, II, III) are composed of three polypeptides $\alpha$-chains (homotrimers or heterotrimers) assembled into a triple-helical structure forming the collagenous domain.
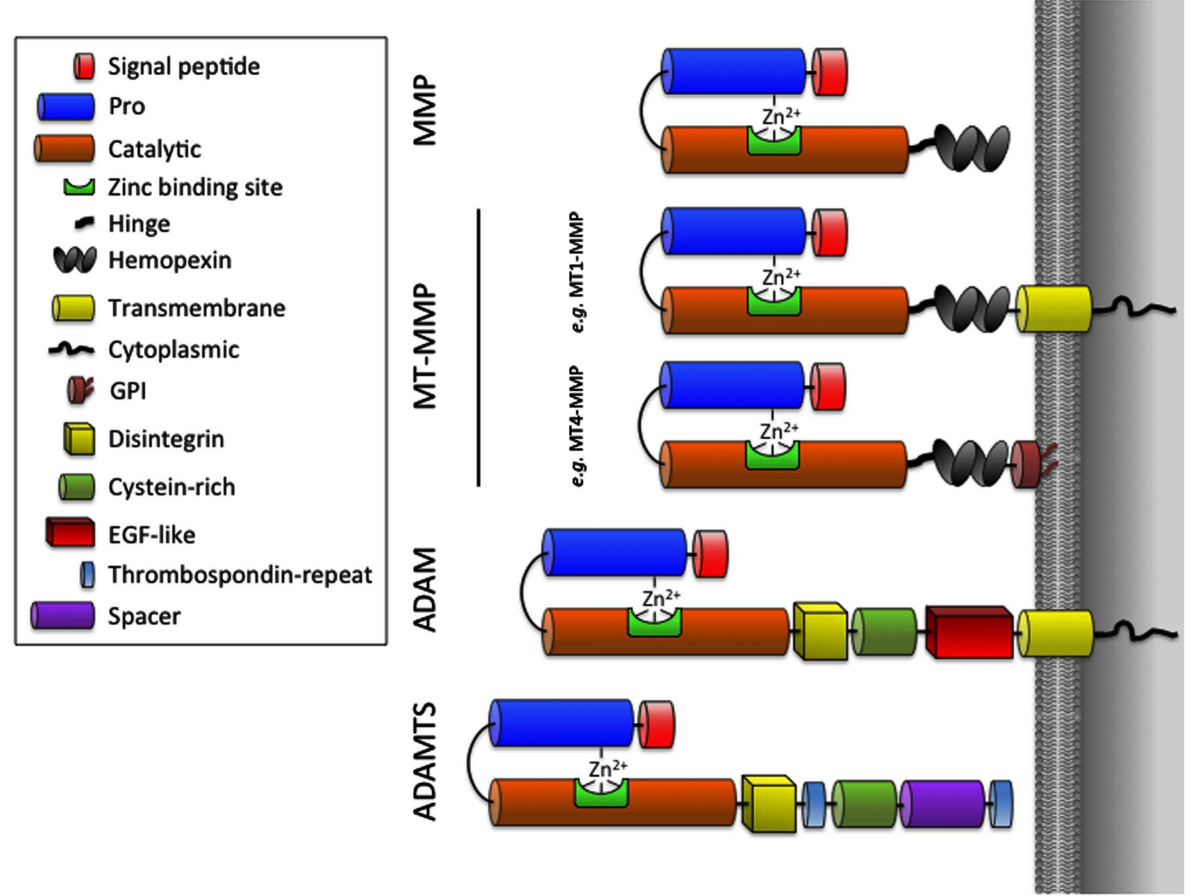

FIGURE 1 | Schematic representation of MMPs, MT-MMPs, ADAMs, and ADAMTSs. 
The N-terminal non-collagenous domain of these fibrillar collagens is proteolytically removed by ADAMTS-2 (Dubail et al., 2010). Interstitial collagenases are the only known mammalian enzymes able to degrade triple-helical fibrillar collagens through specific cleavage of all three $\alpha$-chains at a single locus threequarters from the N-terminus. Collagenolytic MMPs include soluble MMPs (MMP1, MMP8, MMP13) and the membraneassociated MMP14/MT1-MMP, MMP15, and MMP16. More recently, MMP2 has been identified as an interstitial collagenase that can cleave native type I collagen in a distinctive way from other collagenases without generating the classical 3/4 and 1/4 fragments (Egeblad et al., 2007). The very similar gelatinase, MMP9, does not cleave collagen but shares gelatinolytic activity with MMP2 (Vihinen et al., 2005).

Interestingly, microarray analyses have identified collagenolytic MMP1 in a gene expression signature able to predict distant metastasis in breast cancer patients (van't Veer et al., 2002; Gupta et al., 2007). Moreover, MMP1 appears to be a key determinant that selectively mediates lung metastasis in a murine breast cancer model (Minn et al., 2005, 2007; Nguyen and Massague, 2007). MMP13 (collagenase-3) originally identified in human breast cancer tissue (Freije et al., 1994) is viewed as a potential tumor marker for breast cancer diagnosis (Chang et al., 2009) and its expression is correlated with metastasis formation (Ellsworth et al., 2009; Lee et al., 2009). In experimental models, MMP13 appears as a key stromal mediator of cancer progression that regulates the release of angiogenic factors (Lederle et al., 2009) and metastatic dissemination (Zigrino et al., 2009). Interestingly, the presence of microinvasion in ductal carcinoma in situ (DCIS) is associated with focal expression of MMP13 mRNA in stromal fibroblasts (Nielsen et al., 2001, 2007). However, in the aggressive mouse mammary tumor virus-polyoma middle T-antigen (MMTV-PyMT) model of breast cancer, the absence of MMP13 did not influence tumor growth, vascularization, or metastasis to the lungs, suggesting that the role of MMP13 in breast cancer may depend on the nature of the genetic lesions driving malignancy (Nielsen et al., 2008).

MT1-MMP (MMP14) has emerged as an important collagenase that cancer cells use to degrade and invade in a collagenrich environment (Poincloux et al., 2009; Sabeh et al., 2009). Mmp14 ${ }^{-/-}$mice exhibit skeletal defects with craniofacial abnormalities, osteopenia, and impaired angiogenesis (Holmbeck et al., 1999; Zhou et al., 2000). These mutant mice are the unique Mmpdeficient mice generated up to now that are associated with a severe phenotype leading to death after birth. Type I collagen cleavage by MT1-MMP at the endothelial cell-surface stimulates migration, guidance, and organization of endothelial cells into tubular structures (Collen et al., 2003). In the tumor microenvironment, type I collagen remodeling by MT1-MMP enables cancer cells to escape the mechanical barriers confined by the collagen matrix, and stimulates tumor growth in vivo (Hotary et al., 2003). We have recently demonstrated that while poorly invasive breast adenocarcinoma cells undergo apoptosis when confronted with a collagen-rich environment, the production of MT1-MMP endows these cells with the capacity to escape from collagen-induced apoptosis (Maquoi et al., 2012). Beyond its well known gelatinolytic functions, MMP2 also displays interstitial collagenolytic activity (Egeblad et al., 2007) that unexpectedly contributes to lymphangiogenesis, the formation of new lymphatic vessels (Detry et al., 2011). The other gelatinase, MMP9, plays a critical role in tumor-induced angiogenesis through release of vascular endothelial growth factor (VEGF) sequestered from the ECM (Bergers et al., 2000).

In addition to this MMP-driven collagen degradation process, separate pathways, mediated by cysteine protease cathepsins, are operative in acidic extracellular or intracellular microenvironments. The intracellular pathway involves the binding of collagen fibrils to specific cell-surface receptors followed by the cellular uptake and proteolytic degradation of internalized collagen in the lysosomal compartment. One such receptor is uPARAP/Endo180, a member of the macrophage mannose receptor family of endocytic transmembrane glycoproteins. This receptor plays a key role in the cellular uptake and lysosomal degradation of collagen fragments generated through the initial MMP-mediated collagen cleavage (Kjoller et al., 2004; Curino et al., 2005; Engelholm et al., 2009). In cell lines, the amount of internalized collagen correlates with the levels of uPARAP expression (Madsen et al., 2007, 2011). The genetic ablation of uPARAP/Endo 180 in mice demonstrated that the uPARAP-driven endocytic route of collagen breakdown is a rate-limiting factor in collagenolysis by fibroblastic cells, chondrocytes, and osteoclasts (Engelholm et al., 2003; Kjoller et al., 2004; Sulek et al., 2007), as well as in collagen turnover in fibrosis (Bundesmann et al., 2012; Lopez-Guisa et al., 2012; Madsen et al., 2012) and in the invasive growth of breast tumors in mice (Curino et al., 2005). Notably, uPARAP regulates the autolysis and cell-surface level of MT1-MMP reinforcing the functional interplay between two collagen degradation pathways (Kogianni et al., 2009; Messaritou et al., 2009).

\section{PRO-TUMORIGENIC FUNCTIONS OF MT-MMPS}

Beside its role in tumor cells, MT1-MMP is recognized as a crucial regulator of angiogenesis in collagen- or fibrin-rich environments (Chun et al., 2004; Stratman et al., 2009). MT1-MMP's pro-angiogenic capacities in both physiological and pathological conditions are related to several mechanisms including: (1) ECM remodeling (Hotary et al., 2003), (2) interaction with cell-surface molecules, such as CD44 (Kajita et al., 2001) and sphingosine 1-phosphate (S1P; Langlois et al., 2004), (3) degradation of antiangiogenic factors such as decorin in cornea (Mimura et al., 2009), or (4) interaction with TIMP-2 and signaling through ERK1/2 during cell migration (Sounni et al., 2010b). In addition, MT1MMP plays a role in transcriptional and posttranslational control of VEGF expression and bio-availability (Deryugina et al., 2002; Sounni et al., 2002, 2004; Eisenach et al., 2010), as well as in hematopoietic progenitor cell mobilization (Vagima et al., 2009), due to so far unknown molecular mechanisms. Furthermore, a number of recent reports have shed light on an important interplay between MT1-MMP and TGF $\beta$ during angiogenesis and vessel maturation (Tatti et al., 2008; Hawinkels et al., 2010; Sounni et al., 2010a, 2011).

In contrast to MT1-MMP, MT4-MMP is unable to activate proMMP2. Furthermore, MT4-MMP is rather inefficient in hydrolyzing most ECM components compared to the other MT-MMPs (Zucker et al., 2003). Its catalytic domain is able to cleave very few substrates in vitro, including gelatin, fibrin(ogen), 
lipoprotein receptor-related protein, proTNF-alpha, and the aggrecanase ADAMTS-4 (Sohail et al., 2008). The largely overlooked functions of the GPI-anchored MT4-MMP have been explored by the MicroEnviMet partners. In human breast cancer samples, a higher intensity of MT4-MMP immunostaining is observed in cancer cells compared to normal breast epithelial cells (Chabottaux et al., 2006). The overexpression of MT4-MMP in the breast cancer cell line MDA-MB-231 enhances subcutaneous tumor growth and most importantly leads to lung metastasis when cells are inoculated in RAG-1 immunodeficient mice (Chabottaux et al., 2006, 2009). The pro-metastatic effect of MT4-MMP is dependent on its proteolytic activity (Chabottaux et al., 2006) and relies on the induction of an early angiogenic switch (Host et al., 2012) and the perturbation of blood vessel structure characterized by pericyte detachment (Chabottaux et al., 2009). These observations identify MT4-MMP as a cancer cell-derived MMP with pro-angiogenic and pro-metastatic effect that deserves further in-depth investigations.

\section{THE PROTECTIVE EFFECTS OF MMPs AND RELATED ENZYMES}

After years of considering MMPs as pro-tumorigenic enzymes, an intriguing observation has prompted re-evaluation of the roles of MMPs in cancer. In fact, MMP8 deficient mice challenged with carcinogens showed a markedly increased susceptibility to tumorigenesis in comparison with corresponding wild-type mice (Balbin et al., 2003). Further histopathological studies demonstrated that sustained inflammation resulting from MMP8-deficiency creates a permissive environment for cancer progression. Importantly, bone marrow transplantation assays in those mutant mice revealed that MMP8-producing neutrophils are sufficient to rescue the antitumor protection conferred by this enzyme (Balbin et al., 2003). This study provided the first evidence for a protective role of a MMP family member in tumor progression, which has been further extended to other proteases (Lopez-Otin and Matrisian, 2007) as out-lined below. These findings underline the dual functions of host cells that can either boost the tumor or protect the host toward cancer expansion (Figure 2). In addition, MMP8 downregulation in non-metastatic cells increases their metastatic potential (Montel et al., 2004; Gutierrez-Fernandez et al., 2008), and high MMP8 levels in human carcinomas correlate with lower metastasis incidence and a better prognosis to patients with breast or oral cancer (Decock et al., 2007; Korpi et al., 2008). Such antitumor effects or dual functions with protective roles in specific circumstances have been extended to other proteinases including MMP11, MMP12, MMP19, MMP26 (Lopez-Otin and Matrisian, 2007; Lopez-Otin et al., 2009). Furthermore, we reported that ADAMTS-12 exhibits anti-tumorigenic properties by modulating

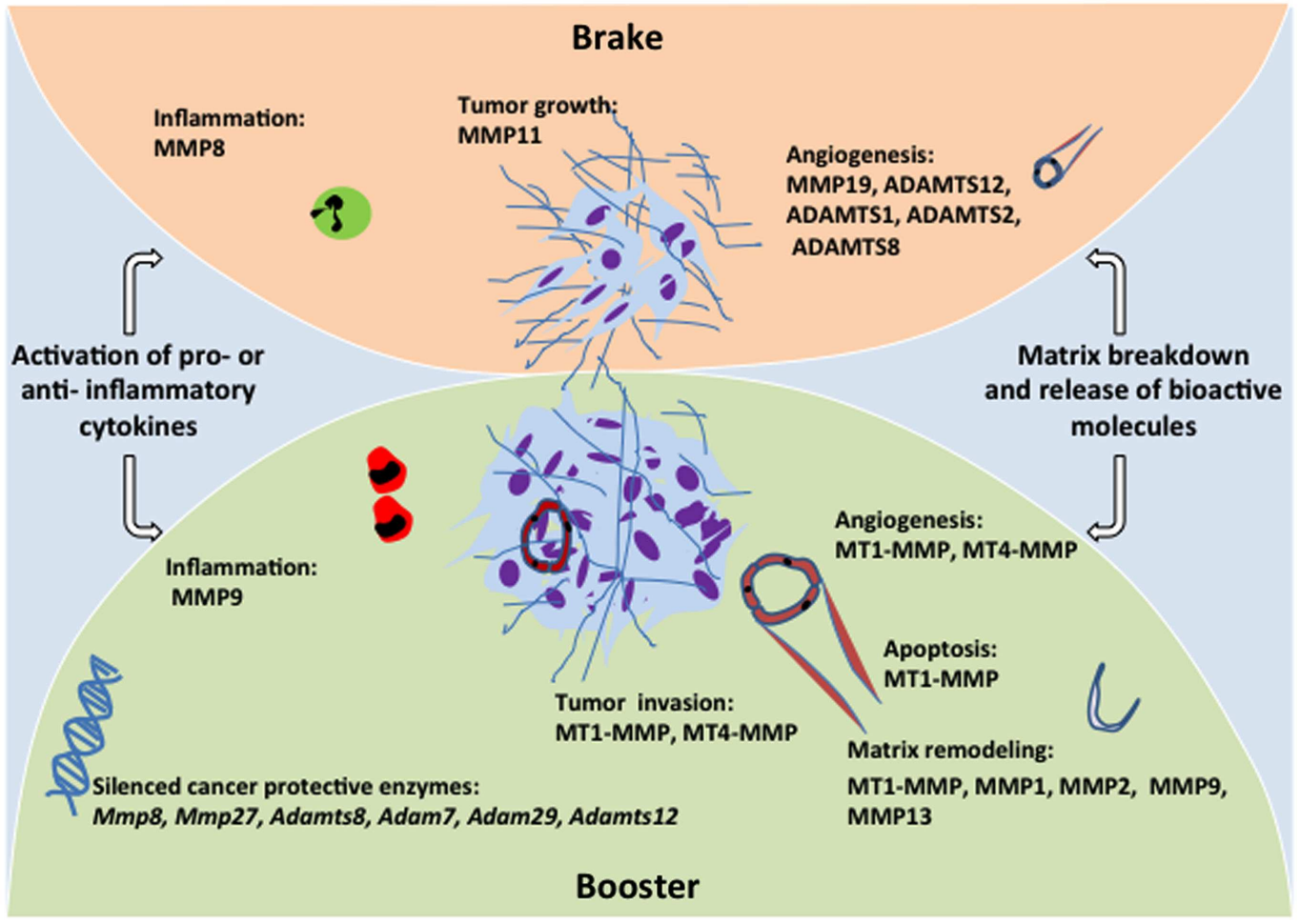

FIGURE 2 | Schematic representation of the brake and booster functions of metalloproteinases. Recent advances in genomic and proteomic technologies have increased our knowledge on MMP contributions to different processes associated with tumor development such as tumor growth, angiogenesis, invasion and inflammation. Despite their implication in ECM remodeling and growth factor signaling that favor angiogenesis and boost tumor development, some metalloproteinases exert protective effects that brake the tumor development. Several cancer protective enzymes are silenced through epigenetic and genetic modifications in malignant cancer. 
Table 1 | Lessons from the past, present advances, and future challenges for MMP inhibition in cancer.

\section{Strategies applied \\ Lessons learnt}

\section{PAST}

Design of broad spectrum MMP inhibitors (MMPIs) in the decade of 1990's: First clinical trials era:

(non-exhaustive list)

Zinc-binding MMPIs

No significant evidence of efficacy, and even adverse effects

Mechanism-based MMPIs

Disconnection between promising preclinical studies and clinical trials, most of them being conducted in patients with late stage tumors

Chemically modified tetracycline

Synthesized peptides

Coussens et al. (2002), Overall and Lopez-Otin (2002), Fingleton (2003), Kruger et al. (2010)

Shark cartilage extracts

Kleifeld et al. (2001), Hu et al. (2007), Devel et al. (2010)

\section{PRESENT}

Novel strategies to generate selective MMPIs:

(non-exhaustive list)

Specific zinc-binding MMPIs

MMPIs without zinc-binding groups

Neutralizing antibodies toward recombinant enzymes

Neutralizing antibodies toward catalytic zinc complex

Non-catalytic hemopexin domain (PEX) inhibitors

Humanizing neutralizing monoclonal antibodies raised in

MMP knock-out mice

Devel et al. (2006, 2010), Devy et al. (2009), Remacle et al

(2012), Sela-Passwell et al. (2012)

Era of MMP complexity elucidation:

MMPs belong to a protease network (protease degradome)

MMPs as cell regulators beyond matrix degradating enzymes

MMPs with intracellular activities

MMPs as builders of the tumor microenvironment in primary and secondary

sites (i.e., inflammation, angiogenesis, lymphangiogenesis)

MMPs with opposite functions depending on cancer type/stage

MMPs with tumor suppressive functions

Lopez-Otin et al. (2009), Cauwe and Opdenakker (2010), Fingleton and Lynch (2010), Kruger et al. (2010), Rodriguez et al. (2010), Hua et al. (2011), Schelter et al. (2011a,b), Sounni et al. (2011), Detry et al. (2012)

\section{FUTURE}

Toward new therapeutic approaches:

Personalized therapy using selective MMPIs combined with

other therapies, including kinase inhibitors

Lopez-Otin and Hunter (2010)

\section{Challenging issues:}

Design of efficient selective inhibitors

Design of appropriate clinical trials and endpoints given the fact that MMP inhibitors are expected to be efficient at early stages

Identification of biomarkers with added values for clinical practice to predict or monitor drug response

Define which patients will benefit from a specific anti-MMP drug and at which disease stage

Fingleton (2007, 2008), Hu et al. (2007), Zucker and Cao (2009), Cauwe and Opdenakker (2010), Decock et al. (2011), Hua et al. (2011) the Ras-dependent ERK pathway (Llamazares et al., 2007). A knock-out mouse strain in which the Adamts-12 gene is deleted (Adamts-12-/-) has been established to elucidate the in vivo functions of ADAMTS-12 (El Hour et al., 2010). A protective effect of host cell-derived ADAMTS-12 is seen when different in vivo models of angiogenesis (malignant keratinocyte transplantation, Matrigel plug, and aortic ring assays) are applied to these knockout mice. In the absence of ADAMTS-12, both the angiogenic response and tumor invasion into host tissue are increased. This finding is in line with the anti-angiogenic functions reported for other ADAMTS family members such as ADAMTS-1, ADAMTS-2, and ADAMTS-8 (Lee et al., 2006; Rodriguez-Manzaneque et al., 2009; Dubail et al., 2010).

Interestingly, recent large-scale genomic studies have explored the possibility that metalloproteinases could be genetically or epigenetically altered in various human malignant tumors. It appears that human melanomas are frequently associated with mutations in $M m p 8$ and Mmp27 genes leading to loss-of-function and enhanced progression of the cancer (Palavalli et al., 2009).
Similarly, somatic mutations are found in Adamts-15 (Viloria et al., 2009) and Adamts-18 (Wei et al., 2010) in human colorectal cancer and melanoma samples, respectively. Likewise, Adam7 and Adam29 genes are frequently mutated in melanoma (Wei et al., 2010). These findings of tumor-specific mutations, likely to affect tumor cell behavior, implicate these genes as drivers in human cancers and underscore the necessity to revisit the initial concept that alteration of proteinase expression was secondary to transcriptional changes rather than genetic mutations. Beyond somatic mutations, several of the ADAMTS genes are epigenetically silenced in various cancers (Moncada-Pazos et al., 2009). The Adamts-12 promoter is hypermethylated in cancer cell lines and tumor tissues leading to reduced production of ADAMTS12 (Moncada-Pazos et al., 2009) that exerts anti-tumorigenic effect (Cal et al., 2002). Remarkably, this epigenetic silencing in the tumor cells is associated with a concurrent overexpression of ADAMTS-12 in the stromal compartment (Moncada-Pazos et al., 2009) where it exerts an anti-angiogenic effect (El Hour et al., 2010). These findings suggest that fibroblasts or more likely 
specific subsets of fibroblasts might react to the presence of tumor cells by overexpressing tumor-inhibiting enzymes. These data provide a strong support for the concept that several proteinases have the ability to apply a brake on cancer cells and protect the host toward cancer progression (Figure 2). Furthermore, they underline the complexity of the tumor-host interface that deserves further in-depth investigation.

\section{CONCLUSION AND PERSPECTIVES}

The emerging picture arising from these studies reveals a complex interplay between tumor-derived proteases produced in cancer cells and tumor associated stromal cells, the surrounding cells and the ECM. Tumor cells acquire some of the required properties for growth and invasion by the specific modification of the tumor microenvironment. However, due to the complex nature of these interactions, it is only by altering specific components of this network that it has been possible to identify proteases with pro-tumorigenic or pro-metastatic functions, as well as proteases with tumor-defying properties. The recent identification of recurrently mutated proteases in melanoma and colorectal cancer highlights the growing list of metalloproteinases with protective functions against tumor development. Nevertheless, the mechanisms by which these proteases exert their pro- or anti-tumorigenic

\section{REFERENCES}

Balbin, M., Fueyo, A., Tester, A. M., Pendas, A. M., Pitiot, A. S., Astudillo, A., Overall, C. M., Shapiro, S. D., and Lopez-Otin, C. (2003). Loss of collagenase- 2 confers increased skin tumor susceptibility to male mice. Nat. Genet. 35, 252-257.

Bergers, G., Brekken, R., McMahon, G., Vu, T. H., Itoh, T., Tamaki, K., Tanzawa, K., Thorpe, P., Itohara, S., Werb, Z., and Hanahan, D. (2000). Matrix metalloproteinase- 9 triggers the angiogenic switch during carcinogenesis. Nat. Cell Biol. 2, 737-744.

Bundesmann, M. M., Wagner, T. E., Chow, Y. H., Altemeier, W. A., Steinbach, T., and Schnapp, L. M. (2012). Role of urokinase plasminogen activator receptor-associated protein in mouse lung. Am. J. Respir. Cell Mol. Biol. 46, 233-239.

Cal, S., Obaya, A. J., Llamazares, M., Garabaya, C., Quesada, V., and Lopez-Otin, C. (2002). Cloning, expression analysis, and structural characterization of seven novel human ADAMTSs, a family of metalloproteinases with disintegrin and thrombospondin-1 domains. Gene 283, 49-62.

Cauwe, B., and Opdenakker, G. (2010). Intracellular substrate cleavage: a novel dimension in the biochemistry, biology and pathology of matrix metalloproteinases. Crit. Rev. Biochem. Mol. Biol. 45, 351-423.

Cauwe, B., Van den Steen, P. E., and Opdenakker, G. (2007). The biochemical, biological, and pathological kaleidoscope of cell surface substrates processed by matrix metalloproteinases. Crit. Rev. Biochem.

Chabottaux, V., Ricaud, S., Host, L., Blacher, S., Paye, A., Thiry, M., Garofalakis, A., Pestourie, C., Gombert, K., Bruyere, F., Lewandowsky, D., Tavitian, B., Foidart, J. M., Duconge, F., and Noel, A. (2009). Membrane-type 4 matrix metalloproteinase (MT4-MMP) induces lung metastasis by alteration of primary breast tumour vascular architecture. J. Cell. Mol. Med. 13, 4002-4013.

Chabottaux, V., Sounni, N. E., Pennington, C. J., English, W. R., van den Brule, F., Blacher, S., Gilles, C., Munaut, C., Maquoi, E., Lopez-Otin, C., Murphy, G., Edwards, D. R., Foidart, J. M., and Noel, A. (2006). Membrane-type 4 matrix metalloproteinase promotes breast cancer growth and metastases. Cancer Res. 66, 5165-5172.

Chang, H. J., Yang, M. J., Yang, Y. H., Hou, M. F., Hsueh, E. J., and Lin, S. R. (2009). MMP13 is potentially a new tumor marker for breast cancer diagnosis. Oncol. Rep. 22, 1119-1127.

Chun, T. H., Sabeh, F., Ota, I., Murphy, H., McDonagh, K. T., Holmbeck, K., Birkedal-Hansen, H., Allen, E. D., and Weiss, S. J. (2004). MT1-MMP-dependent neovessel formation within the confines of the three-dimensional Mol. Biol. 42, 113-185.

properties at the molecular level are largely unknown and represent a challenging issue for the near future. In fact, several MMPs, such as MMP9 or MMP12, might have dual roles either promoting or suppressing tumorigenesis depending on the type of cell in which they are expressed. Given that MMP family members can exert promoting or protective effects and that some individual MMPs can display opposite roles in different cancer types or phases of progression, a required step toward personalized cancer therapy is now the identification of the most appropriate $\mathrm{MMP}(\mathrm{s})$ to be targeted in each case. Discerning which $\mathrm{MMP}(\mathrm{s})$ to target and when to inhibit are major issues that are facing researchers in the field. In addition, the design of highly selective MMP inhibitors is mandatory to overcome the failure of broad spectrum MMP inhibitors in clinical trials (Table 1). In this context, novel strategies are emerging to generate new specific synthetic inhibitors or neutralizing antibodies (Table 1). Hopefully, the clarification of these questions will finally result in clinical introduction of inhibitors of selected matrix-remodeling enzymes as new components of anticancer therapies.

\section{ACKNOWLEDGMENTS}

This work was supported by grants from the FP7-HEALTH-F22008-201279 “MICROENVIMET."

extracellular matrix. J. Cell Biol. 167, 757-767.

Colige, A., Ruggiero, F., Vandenberghe, I., Dubail, J., Kesteloot, F., Van Beeumen, J., Beschin, A., Brys, L., Lapiere, C. M., and Nusgens, B. (2005). Domains and maturation processes that regulate the activity of ADAMTS-2, a metalloproteinase cleaving the aminopropeptide of fibrillar procollagens types I-III and V. J. Biol. Chem. 280, 34397-34408.

Collen, A., Hanemaaijer, R., Lupu, F., Quax, P. H., van Lent, N., Grimbergen, J., Peters, E., Koolwijk, P., and van Hinsbergh, V. W. (2003). Membrane-type matrix metalloproteinase-mediated angiogenesis in a fibrin-collagen matrix. Blood 101, 1810-1817.

Coussens, L. M., Fingleton, B. B., and Matrisian, L. M. (2002). Matrix metalloproteinase inhibitors and cancer: trials and tribulations. Science 295, 2387-2392.

Coussens, L. M., and Werb, Z. (2001). Inflammatory cells and cancer: think different! J. Exp. Med. 193, F23-F26.

Curino, A. C., Engelholm, L. H., Yamada, S. S., Holmbeck, K., Lund, L. R., Molinolo, A. A., Behrendt, N., Nielsen, B. S., and Bugge, T. H. (2005). Intracellular collagen degradation mediated by UPARAP/Endo 180 is a major pathway of extracellular matrix turnover during malignancy. J. Cell Biol. 169, 977-985.
Decock, J., Hendrickx, W., Drijkoningen, M., Wildiers, H., Neven, P., Smeets, A., and Paridaens, R. (2007). Matrix metalloproteinase expression patterns in luminal A type breast carcinomas. Dis. Markers 23, 189-196.

Decock, J., Thirkettle, S., Wagstaff, L., and Edwards, D. R. (2011) Matrix metalloproteinases: protective roles in cancer. J. Cell Mol. Med. 15, 1254-1265.

Deryugina, E. I., Soroceanu, L., and Strongin, A. Y. (2002). Upregulation of vascular endothelial growth factor by membrane-type 1 matrix metalloproteinase stimulates human glioma xenograft growth and angiogenesis. Cancer Res. 62, 580-588.

Detry, B., Bruyere, F., Erpicum, C., Paupert, J., Lamaye, F., Maillard, C., Lenoir, B., Foidart, J. M., Thiry, M., and Noel, A. (2011). Digging deeper into lymphatic vessel formation in vitro and in vivo. BMC Cell Biol. 12, 29. doi:10.1186/1471-212112-29

Detry, B., Erpicum, C., Paupert, J., Blacher, S., Maillard, C., Bruyere, F., Pendeville, H., Remacle, T., Lambert, V., Balsat, C., Ormenese, S., Lamaye, F., Janssens, E., Moons, L., Cataldo, D., Kridelka, F., Carmeliet, P., Thiry, M., Foidart, J. M., Struman, I., and Noel, A. (2012). Matrix metalloproteinase-2 governs lymphatic vessel formation as an interstitial collagenase. Blood 119, 5048-5056. 
Devel, L., Czarny, B., Beau, F., Georgiadis, D., Stura, E., and Dive, V. (2010). Third generation of matrix metalloprotease inhibitors: gain in selectivity by targeting the depth of the S1' cavity. Biochimie 92, 1501-1508.

Devel, L., Rogakos, V., David, A., Makaritis, A., Beau, F., Cuniasse, P., Yiotakis, A., and Dive, V. (2006). Development of selective inhibitors and substrate of matrix metalloproteinase-12. J. Biol. Chem. 281, 11152-11160.

Devy, L., Huang, L., Naa, L., Yanamandra, N., Pieters, H., Frans, N., Chang, E., Tao, Q., Vanhove, M., Lejeune, A., van Gool, R., Sexton, D. J., Kuang, G., Rank, D., Hogan, S., Pazmany, C., Ma, Y. L., Schoonbroodt, S., Nixon, A. E., Ladner, R. C., Hoet, R., Henderikx, P., Tenhoor, C., Rabbani, S. A., Valentino, M. L., Wood, C. R., and Dransfield, D. T. (2009). Selective inhibition of matrix metalloproteinase-14 blocks tumor growth, invasion, and angiogenesis. Cancer Res. 69, 1517-1526.

Dubail, J., Kesteloot, F., Deroanne, C., Motte, P., Lambert, V., Rakic, J. M., Lapiere, C., Nusgens, B., and Colige, A. (2010). ADAMTS-2 functions as anti-angiogenic and anti-tumoral molecule independently of its catalytic activity. Cell. Mol. Life Sci. 67, 4213-4232.

Egeblad, M., Shen, H. C., Behonick, D. J., Wilmes, L., Eichten, A., Korets, L. V., Kheradmand, F., Werb, Z., and Coussens, L. M. (2007). Type I collagen is a genetic modifier of matrix metalloproteinase 2 in murine skeletal development. Dev. Dyn. 236, 1683-1693.

Egeblad, M., and Werb, Z. (2002). New functions for the matrix metalloproteinases in cancer progression. Nat. Rev. Cancer 2, 161-174.

Eisenach, P. A., Roghi, C., Fogarasi, M., Murphy, G., and English, W. R. (2010). MT1-MMP regulates VEGFA expression through a complex with VEGFR-2 and Src. J. Cell. Sci. 123, 4182-4193.

El Hour, M., Moncada-Pazos, A., Blacher, S., Masset, A., Cal, S., Berndt, S., Detilleux, J., Host, L., Obaya, A. J., Maillard, C., Foidart, J. M., Ectors, F., Noel, A., and LopezOtin, C. (2010). Higher sensitivity of Adamts12-deficient mice to tumor growth and angiogenesis. Oncogene 29, 3025-3032.

Ellsworth, R. E., Hooke, J. A., Shriver, C. D., and Ellsworth, D. L. (2009). Genomic heterogeneity of breast tumor pathogenesis. Clin. Med. Oncol. 3, 77-85.
Engelholm, L. H., Ingvarsen, S., Jurgensen, H. J., Hillig, T., Madsen, D. H., Nielsen, B. S., and Behrendt, N. (2009). The collagen receptor uPARAP/Endo180. Front. Biosci. 14, 2103-2114.

Engelholm, L. H., List, K., NetzelArnett, S., Cukierman, E., Mitola, D. J., Aaronson, H., Kjoller, L., Larsen, J. K., Yamada, K. M., Strickland, D. K., Holmbeck, K., Dano, K., Birkedal-Hansen, H., Behrendt, N., and Bugge, T. H. (2003). uPARAP/Endo180 is essential for cellular uptake of collagen and promotes fibroblast collagen adhesion. J. Cell Biol. 160, 1009-1015.

Erler, J. T., Bennewith, K. L., Cox, T. R., Lang, G., Bird, D., Koong, A., Le, Q. T., and Giaccia, A. J. (2009). Hypoxia-induced lysyl oxidase is a critical mediator of bone marrow cell recruitment to form the premetastatic niche. Cancer Cell 15, 35-44.

Erler, J. T., and Weaver, V. M. (2009). Three-dimensional context regulation of metastasis. Clin. Exp. Metastasis 26, 35-49.

Fanjul-Fernandez, M., Folgueras, A. R., Cabrera, S., and Lopez-Otin, C. (2010). Matrix metalloproteinases: evolution, gene regulation and functional analysis in mouse models. Biochim. Biophys. Acta 1803, 3-19.

Finak, G., Bertos, N., Pepin, F., Sadekova, S., Souleimanova, M., Zhao, H., Chen, H., Omeroglu, G., Meterissian, S., Omeroglu, A., Hallett, M., and Park, M. (2008). Stromal gene expression predicts clinical outcome in breast cancer. Nat. Med. 14, 518-527.

Fingleton, B. (2003). Matrix metalloproteinase inhibitors for cancer therapy: the current situation and future prospects. Expert Opin. Ther. Targets 7, 385-397.

Fingleton, B. (2007). Matrix metalloproteinases as valid clinical targets. Curr. Pharm. Des. 13, 333-346.

Fingleton, B. (2008). MMPs as therapeutic targets-still a viable option? Semin. Cell Dev. Biol. 19, 61-68.

Fingleton, B., and Lynch, C. C. (2010). A new dress code for MMPs: cleavage optional. Dev. Cell 18, 3-4.

Folgueras, A. R., Pendas, A. M., Sanchez, L. M., and Lopez-Otin, C. (2004). Matrix metalloproteinases in cancer: from new functions to improved inhibition strategies. Int. J. Dev. Biol. $48,411-424$.

Freije, J. M., Diez-Itza, I., Balbin, M., Sanchez, L. M., Blasco, R., Tolivia, J., and Lopez-Otin, C. (1994). Molecular cloning and expression of collagenase-3, a novel human matrix metalloproteinase produced by breast carcinomas. J. Biol. Chem. 269, 16766-16773.

Gupta, G. P., Perk, J., Acharyya, S., de Candia, P., Mittal, V., TodorovaManova, K., Gerald, W. L., Brogi, E., Benezra, R., and Massague, J. (2007). ID genes mediate tumor reinitiation during breast cancer lung metastasis. Proc. Natl. Acad. Sci. U.S.A. 104 19506-19511.

Gutierrez-Fernandez, A., Fueyo, A. Folgueras, A. R., Garabaya, C., Pennington, C. J., Pilgrim, S., Edwards, D. R., Holliday, D. L., Jones, J. L., Span, P. N., Sweep, F. C., Puente, X. S., and Lopez-Otin, C. (2008). Matrix metalloproteinase- 8 functions as a metastasis suppressor through modulation of tumor cell adhesion and invasion. Cancer Res. 68, 2755-2763.

Hanahan, D., and Weinberg, R. A. (2011). Hallmarks of cancer: the next generation. Cell 144, 646-674.

Handsley, M. M., and Edwards, D. R. (2005). Metalloproteinases and their inhibitors in tumor angiogenesis. Int. J. Cancer 115, 849-860.

Hasebe, T., Sasaki, S., Imoto, S., Mukai, K., Yokose, T., and Ochiai, A. (2002). Prognostic significance of fibrotic focus in invasive ductal carcinoma of the breast: a prospective observational study. Mod. Pathol. 15, 502-516.

Hawinkels, L. J., Kuiper, P., Wiercinska, E., Verspaget, H. W., Liu, Z., Pardali, E., Sier, C. F., and ten Dijke, P. (2010). Matrix metalloproteinase-14 (MT1MMP)-mediated endoglin shedding inhibits tumor angiogenesis. Cancer Res. 70, 4141-4150.

Holmbeck, K., Bianco, P., and BirkedalHansen, B. (2003). MT1-MMP: a collagenase essential for tumor cell invasive growth. Cancer Cell. 81-84.

Holmbeck, K., Bianco, P., Caterina, J., Yamada, S., Kromer, M., Kuznetsov, S. A., Mankani, M., Robey, P. G., Poole, A. R., Pidoux, I., Ward, J. M., and Birkedal-Hansen, H. (1999). MT1-MMP-deficient mice develop dwarfism, osteopenia, arthritis, and connective tissue disease due to inadequate collagen turnover. Cell 99, 81-92.

Host, L., Paye, A., Detry, B., Blacher, S., Munaut, C., Foidart, J. M., Seiki, M., Sounni, N. E., and Noel, A. (2012). The proteolytic activity of MT4-MMP is required for its proangiogenic and pro-metastatic promoting effects. Int. J. Cancer. doi: $10.1002 /$ ijc. 27436

Hotary, K. B., Allen, E. D., Brooks, P. C., Datta, N. S., Long, M. W., and Weiss, S. J. (2003). Membrane type
I matrix metalloproteinase usurps tumor growth control imposed by the three-dimensional extracellular matrix. Cell 114, 33-45.

Hu, J., Van den Steen, P. E., Sang, Q. X., and Opdenakker, G. (2007). Matrix metalloproteinase inhibitors as therapy for inflammatory and vascular diseases. Nat. Rev. Drug Discov. 6, 480-498.

Hua, H., Li, M., Luo, T., Yin, Y., and Jiang, Y. (2011). Matrix metalloproteinases in tumorigenesis: an evolving paradigm. Cell. Mol. Life Sci. 68, 3853-3868

Hubmacher, D., and Apte, S. S. (2011). Genetic and functional linkage between ADAMTS superfamily proteins and fibrillin-1: a novel mechanism influencing microfibril assembly and function. Cell. Mol. Life Sci. 68, 3137-3148.

Joyce, J. A., and Pollard, J. W. (2009). Microenvironmental regulation of metastasis. Nat. Rev. Cancer 9, 239-252.

Kajita, M., Itoh, Y., Chiba, T., Mori, H., Okada, A., Kinoh, H., and Seiki, M. (2001). Membrane-type 1 matrix metalloproteinase cleaves CD44 and promotes cell migration. J. Cell Biol. 153, 893-904.

Kalluri, R. (2003). Basement membranes: structure, assembly and role in tumour angiogenesis. Nat. Rev. Cancer 3, 422-433.

Kalluri, R., and Zeisberg, M. (2006). Fibroblasts in cancer. Nat. Rev. Cancer 6, 392-401.

Kessenbrock, K., Plaks, V., and Werb, Z. (2010). Matrix metalloproteinases: regulators of the tumor microenvironment. Cell 141, 52-67.

Kjoller, L., Engelholm, L. H., HoyerHansen, M., Dano, K., Bugge, T. H., and Behrendt, N. (2004). uPARAP/endo180 directs lysosomal delivery and degradation of collagen IV. Exp. Cell Res. 293, 106-116.

Kleifeld, O., Kotra, L. P., Gervasi, D. C., Brown, S., Bernardo, M. M., Fridman, R., Mobashery, S., and Sagi, I. (2001). X-Ray absorption studies of human matrix metalloproteinase-2 (MMP-2) bound to a highly selective mechanism-based inhibitor. Comparison with the latent and active forms of the enzyme. J. Biol. Chem. 276, 17125-17131.

Klein, T., and Bischoff, R. (2011). Active metalloproteases of the A disintegrin and metalloprotease (ADAM) family: biological function and structure. J. Proteome Res. 10, 17-33.

Kogianni, G., Walker, M. M., Waxman, J., and Sturge, J. (2009). Endo180 expression with cofunctional partners MT1-MMP and uPAR-uPA is 
correlated with prostate cancer progression. Eur. J. Cancer 45, 685-693.

Korpi, J. T., Kervinen, V., Maklin, H., Vaananen, A., Lahtinen, M., Laara, E., Ristimaki, A., Thomas, G., Ylipalosaari, M., Astrom, P., LopezOtin, C., Sorsa, T., Kantola, S., Pirila, E., and Salo, T. (2008). Collagenase-2 (matrix metalloproteinase-8) plays a protective role in tongue cancer. $\mathrm{Br}$. J. Cancer 98, 766-775.

Kruger, A., Kates, R. E., and Edwards, D. R. (2010). Avoiding spam in the proteolytic internet: future strategies for anti-metastatic MMP inhibition. Biochim. Biophys. Acta 1803, 95-102.

Langlois, S., Gingras, D., and Beliveau, R. (2004). Membrane type 1-matrix metalloproteinase (MT1MMP) cooperates with sphingosine 1-phosphate to induce endothelial cell migration and morphogenic differentiation. Blood 103, 3020-3028.

Lederle, W., Hartenstein, B., Meides, A., Kunzelmann, H., Werb, Z., Angel, P., and Mueller, M. M. (2009). MMP13 as a stromal mediator in controlling persistent angiogenesis in skin carcinoma. Carcinogenesis 31, 1175-1184.

Lee, C. F., Ling, Z. Q., Zhao, T., Fang, S. H., Chang, W.C., Lee, S. C., and Lee, K. R. (2009). Genomic-wide analysis of lymphatic metastasis-associated genes in human hepatocellular carcinoma. World J. Gastroenterol. 15, 356-365.

Lee, N. V., Sato, M., Annis, D. S., Loo, J. A., Wu, L., Mosher, D. F., and IruelaArispe, M. L. (2006). ADAMTS1 mediates the release of antiangiogenic polypeptides from TSP1 and 2. EMBO J. 25, 5270-5283.

Llamazares, M., Obaya, A. J., MoncadaPazos, A., Heljasvaara, R., Espada, J., Lopez-Otin, C., and Cal, S. (2007). The ADAMTS12 metalloproteinase exhibits anti-tumorigenic properties through modulation of the Rasdependent ERK signalling pathway. J. Cell. Sci. 120, 3544-3552.

Lopez-Guisa, J. M., Cai, X., Collins, S. J., Yamaguchi, I., Okamura, D. M., Bugge, T. H., Isacke, C. M., Emson, C. L., Turner, S. M., Shankland, S. J., and Eddy, A. A. (2012). Mannose receptor 2 attenuates renal fibrosis. J. Am. Soc. Nephrol. 23, 236-251.

Lopez-Otin, C., and Hunter, T. (2010). The regulatory crosstalk between kinases and proteases in cancer. Nat. Rev. Cancer 10, 278-292.

Lopez-Otin, C., and Matrisian, L. M. (2007). Tumour microenvironment: emerging roles of proteases in tumour suppression. Nat. Rev. Cancer 7, 800-808.
Lopez-Otin, C., and Overall, C. M. (2002). Protease degradomics: a new challenge for proteomics. Nat. Rev. Mol. Cell Biol. 3, 509-519.

Lopez-Otin, C., Palavalli, L. H., and Samuels, Y. (2009). Protective roles of matrix metalloproteinases: from mouse models to human cancer. Cell Cycle 8, 3657-3662.

Lu, P., Weaver, V. M., and Werb, Z. (2012). The extracellular matrix: a dynamic niche in cancer progression. J. Cell Biol. 196, 395-406.

Madsen, D. H., Engelholm, L. H., Ingvarsen, S., Hillig, T., WagenaarMiller, R. A., Kjoller, L., Gardsvoll, H., Hoyer-Hansen, G., Holmbeck, K., Bugge, T. H., and Behrendt, N. (2007). Extracellular collagenases and the endocytic receptor, urokinase plasminogen activator receptor-associated protein/Endo180, cooperate in fibroblast-mediated collagen degradation. J. Biol. Chem. 282, 27037-27045.

Madsen, D. H., Ingvarsen, S., Jurgensen, H. J., Melander, M. C., Kjoller, L., Moyer, A., Honore, C., Madsen, C. A., Garred, P., Burgdorf, S., Bugge, T. H., Behrendt, N., and Engelholm, L. H. (2011). The non-phagocytic route of collagen uptake: a distinct degradation pathway. J. Biol. Chem. 286, 26996-27010.

Madsen, D. H., Jurgensen, H. J., Ingvarsen, S., Melander, M. C., Vainer, B., Egerod, K. L., Hald, A., Rono, B., Madsen, C. A., Bugge, T. H., Engelholm, L. H., and Behrendt, N. (2012). Endocytic collagen degradation: a novel mechanism involved in protection against liver fibrosis. $J$. Pathol. 227, 94-105.

Maquoi, E., Assent, D., Detilleux, J., Pequeux, C., Foidart, J. M., and Noel, A. (2012). MT1-MMP protects breast carcinoma cells against type I collagen-induced apoptosis. Oncogene 31, 480-493.

Messaritou, G., East, L., Roghi, C., Isacke, C. M., and Yarwood, H. (2009). Membrane type-1 matrix metalloproteinase activity is regulated by the endocytic collagen receptor Endo180. J. Cell. Sci. 122, 4042-4048.

Mimura, T., Han, K. Y., Onguchi, T., Chang, J. H., Kim, T. I., Kojima, T., Zhou, Z., and Azar, D. T. (2009). MT1-MMP-mediated cleavage of decorin in corneal angiogenesis. $J$. Vasc. Res. 46, 541-550.

Minn, A. J., Gupta, G. P., Padua, D., Bos, P., Nguyen, D. X., Nuyten, D., Kreike, B., Zhang, Y., Wang, Y., Ishwaran, H., Foekens, J. A., van de Vijver, M., and Massague, J. (2007). Lung metastasis genes couple breast tumor size and metastatic spread. Proc. Natl. Acad. Sci. U.S.A. 104, 6740-6745.

Minn, A. J., Gupta, G. P., Siegel, P. M. Bos, P. D., Shu, W., Giri, D. D., Viale, A., Olshen, A. B., Gerald, W. L., and Massague, J. (2005). Genes that mediate breast cancer metastasis to lung. Nature 436, 518-524.

Moncada-Pazos, A., Obaya, A. J., Fraga, M. F., Viloria, C. G., Capella, G., Gausachs, M., Esteller, M., LopezOtin, C., and Cal, S. (2009). The ADAMTS12 metalloprotease gene is epigenetically silenced in tumor cells and transcriptionally activated in the stroma during progression of colon cancer. J. Cell. Sci. 122, 2906-2913.

Montel, V., Kleeman, J., Agarwal, D., Spinella, D., Kawai, K., and Tarin, D. (2004). Altered metastatic behavior of human breast cancer cells after experimental manipulation of matrix metalloproteinase 8 gene expression. Cancer Res. 64, 1687-1694.

Nguyen, D. X., and Massague, J. (2007). Genetic determinants of cancer metastasis. Nat. Rev. Genet. 8, 341-352.

Nielsen, B. S., Egeblad, M., Rank, F., Askautrud, H. A., Pennington, C. J., Pedersen, T. X., Christensen, I. J., Edwards, D. R., Werb, Z., and Lund, L. R. (2008). Matrix metalloproteinase 13 is induced in fibroblasts in polyomavirus middle $\mathrm{T}$ antigen-driven mammary carcinoma without influencing tumor progression. PLoS ONE 3, e2959. doi:10.1371/journal.pone.0002959

Nielsen, B. S., Rank, F., Illemann, M., Lund, L. R., and Dano, K. (2007). Stromal cells associated with early invasive foci in human mammary ductal carcinoma in situ coexpress urokinase and urokinase receptor. Int. J. Cancer 120, 2086-2095.

Nielsen, B. S., Rank, F., Lopez, J. M., Balbin, M., Vizoso, F., Lund, L. R., Dano, K., and Lopez-Otin, C. (2001). Collagenase-3 expression in breast myofibroblasts as a molecular marker of transition of ductal carcinoma in situ lesions to invasive ductal carcinomas. Cancer Res. 61, 7091-7100.

Noel, A., Jost, M., and Maquoi, E. (2008). Matrix metalloproteinases at cancer tumor-host interface. Semin. Cell Dev. Biol. 19, 52-60.

Overall, C. M., and Kleifeld, O. (2006). Tumour microenvironmentopinion: validating matrix metalloproteinases as drug targets and anti-targets for cancer therapy. Nat. Rev. Cancer 6, 227-239.
Overall, C. M., and Lopez-Otin, C. (2002). Strategies for MMP inhibition in cancer: innovations for the post-trial era. Nat. Rev. Cancer 2, 657-672.

Page-McCaw, A., Ewald, A. J., and Werb, Z. (2007). Matrix metalloproteinases and the regulation of tissue remodelling. Nat. Rev. Mol. Cell Biol. 8, 221-233.

Palavalli, L. H., Prickett, T. D., Wunderlich, J. R., Wei, X., Burrell, A. S., Porter-Gill, P., Davis, S., Wang, C., Cronin, J. C., Agrawal, N. S., Lin, J. C., Westbroek, W., HoogstratenMiller, S., Molinolo, A. A., Fetsch, P., Filie, A. C., O’Connell, M. P., Banister, C. E., Howard, J. D., Buckhaults, P., Weeraratna, A. T., Brody, L. C., Rosenberg, S. A., and Samuels, Y. (2009). Analysis of the matrix metalloproteinase family reveals that MMP8 is often mutated in melanoma. Nat. Genet. 41, 518-520.

Poincloux, R., Lizarraga, F., and Chavrier, P. (2009). Matrix invasion by tumour cells: a focus on MT1MMP trafficking to invadopodia. J. Cell. Sci. 122, 3015-3024.

Ramaswamy, S., Ross, K. N., Lander, E. S., and Golub, T. R. (2003). A molecular signature of metastasis in primary solid tumors. Nat. Genet. 33, 49-54.

Remacle, A. G., Golubkov, V. S., Shiryaev, S. A., Dahl, R., Stebbins, J. L., Chernov, A. V., Cheltsov, A. V., Pellecchia, M., and Strongin, A. Y. (2012). Novel MT1-MMP small-molecule inhibitors based on insights into hemopexin domain function in tumor growth. Cancer Res. 72, 2339-2349.

Rocks, N., Paulissen, G., El Hour, M., Quesada, F., Crahay, C., Gueders, M., Foidart, J. M., Noel, A., and Cataldo, D. (2008). Emerging roles of ADAM and ADAMTS metalloproteinases in cancer. Biochimie 90, 369-379.

Rodriguez, D., Morrison, C. J., and Overall, C. M. (2010). Matrix metalloproteinases: what do they not do? New substrates and biological roles identified by murine models and proteomics. Biochim. Biophys. Acta 1803, 39-54.

Rodriguez-Manzaneque, J. C., Carpizo, D., Plaza-Calonge Mdel, C., TorresCollado, A. X., Thai, S. N., Simons, M., Horowitz, A., and Iruela-Arispe, M. L. (2009). Cleavage of syndecan4 by ADAMTS1 provokes defects in adhesion. Int. J. Biochem. Cell Biol. 41, 800-810.

Sabeh, F., Li, X. Y., Saunders, T. L., Rowe, R. G., and Weiss, S. J. 
(2009). Secreted versus membraneanchored collagenases: relative roles in fibroblast-dependent collagenolysis and invasion. J. Biol. Chem. 284, 23001-23011.

Schelter, F., Grandl, M., Seubert, B., Schaten, S., Hauser, S., Gerg, M., Boccaccio, C., Comoglio, P., and Kruger, A. (2011a). Tumor cellderived Timp-1 is necessary for maintaining metastasis-promoting Met-signaling via inhibition of Adam-10. Clin. Exp. Metastasis 28, 793-802.

Schelter, F., Halbgewachs, B., Baumler, P., Neu, C., Gorlach, A., Schrotzlmair, F., and Kruger, A. (2011b). Tissue inhibitor of metalloproteinases1-induced scattered liver metastasis is mediated by hypoxia-inducible factor-1alpha. Clin. Exp. Metastasis 28, 91-99.

Sela-Passwell, N., Kikkeri, R., Dym, O., Rozenberg, H., Margalit, R., Arad-Yellin, R., Eisenstein, M., Brenner, O., Shoham, T., Danon, T., Shanzer, A., and Sagi, I. (2012). Antibodies targeting the catalytic zinc complex of activated matrix metalloproteinases show therapeutic potential. Nat. Med. 18, 143-147.

Sohail, A., Sun, Q., Zhao, H., Bernardo, M. M., Cho, J. A., and Fridman, R. (2008). MT4-(MMP17) and MT6MMP (MMP25), a unique set of membrane-anchored matrix metalloproteinases: properties and expression in cancer. Cancer Metastasis Rev. 27, 289-302.

Sounni, N. E., Dehne, K., van Kempen, L., Egeblad, M., Affara, N. I., Cuevas, I., Wiesen, J., Junankar, S., Korets, L., Lee, J., Shen, J., Morrison, C. J., Overall, C. M., Krane, S. M., Werb, Z., Boudreau, N., and Coussens, L. M. (2010a). Stromal regulation of vessel stability by MMP14 and TGFbeta. Dis Model Mech. 3, 317-332.

Sounni, N. E., Rozanov, D. V., Remacle, A. G., Golubkov, V. S., Noel, A., and Strongin, A. Y. (2010b). Timp-2 binding with cellular MT1-MMP stimulates invasion-promoting MEK/ERK signaling in cancer cells. Int. J. Cancer 126, 1067-1078.

Sounni, N. E., Devy, L., Hajitou, A., Frankenne, F., Munaut, C., Gilles,
C., Deroanne, C., Thompson, E. W., Foidart, J. M., and Noel, A. (2002). MT1-MMP expression promotes tumor growth and angiogenesis through an up-regulation of vascular endothelial growth factor expression. FASEB J. 16, 555-564.

Sounni, N. E., and Noel, A. (2005). Membrane type-matrix metalloproteinases and tumor progression. Biochimie 87, 329-342.

Sounni, N. E., Paye, A., Host, L., and Noël, A. (2011). MT-MMPs as regulators of vessel stability associated with angiogenesis. Front. Pharmacol. 2:111. doi:10.3389/fphar.2011.00111

Sounni, N. E., Roghi, C., Chabottaux, V., Janssen, M., Munaut, C., Maquoi, E., Galvez, B. G., Gilles, C., Frankenne, F., Murphy, G., Foidart, J. M., and Noel, A. (2004). Up-regulation of vascular endothelial growth factor-A by active membrane-type 1 matrix metalloproteinase through activation of Srctyrosine kinases. J. Biol. Chem. 279, 13564-13574.

Spaeth, E. L., Dembinski, J. L., Sasser, A. K., Watson, K., Klopp, A., Hall, B., Andreeff, M., and Marini, F. (2009). Mesenchymal stem cell transition to tumor-associated fibroblasts contributes to fibrovascular network expansion and tumor progression. PLoS ONE 4, e4992. doi:10.1371/journal.pone.0004992

Stratman, A. N., Saunders, W. B., Sacharidou, A., Koh, W., Fisher, K. E., Zawieja, D. C., Davis, M. J., and Davis, G. E. (2009). Endothelial cell lumen and vascular guidance tunnel formation requires MT1-MMP-dependent proteolysis in 3-dimensional collagen matrices. Blood 114, 237-247.

Strongin, A. Y. (2010). Proteolytic and non-proteolytic roles of membrane type-1 matrix metalloproteinase in malignancy. Biochim. Biophys. Acta 1803, 133-141.

Sulek, J., Wagenaar-Miller, R. A., Shireman, J., Molinolo, A., Madsen, D. H., Engelholm, L. H., Behrendt, N., and Bugge, T. H. (2007). Increased expression of the collagen internalization receptor uPARAP/Endo180 in the stroma of head and neck cancer. J. Histochem. Cytochem. 55, 347-353.

Tatti, O., Vehvilainen, P., Lehti, K., and Keski-Oja, J. (2008). MT1MMP releases latent TGF-betal from endothelial cell extracellular matrix via proteolytic processing of LTBP-1. Exp. Cell Res. 314, 2501-2514.

Tavazoie, S. F., Alarcon, C., Oskarsson, T., Padua, D., Wang, Q., Bos, P. D., Gerald, W. L., and Massague, J. (2008). Endogenous human microRNAs that suppress breast cancer metastasis. Nature 451, 147-152.

Vagima, Y., Avigdor, A., Goichberg, P., Shivtiel, S., Tesio, M., Kalinkovich, A., Golan, K., Dar, A., Kollet, O. Petit, I., Perl, O., Rosenthal, E., Resnick, I., Hardan, I., Gellman, Y. N., Naor, D., Nagler, A., and Lapidot, T. (2009). MT1-MMP and RECK are involved in human $\mathrm{CD} 34+$ progenitor cell retention, egress, and mobilization. J. Clin. Invest. 119, 492-503.

van't Veer, L. J., Dai, H., van de Vijver, M. J., He, Y. D., Hart, A. A., Mao, M., Peterse, H. L., van der Kooy, K., Marton, M. J., Witteveen, A. T. Schreiber, G. J., Kerkhoven, R. M., Roberts, C., Linsley, P. S., Bernards, R., and Friend, S. H. (2002). Gene expression profiling predicts clinical outcome of breast cancer. Nature 415, 530-536.

Viloria, C. G., Obaya, A. J., MoncadaPazos, A., Llamazares, M., Astudillo, A., Capella, G., Cal, S., and LopezOtin, C. (2009). Genetic inactivation of ADAMTS15 metalloprotease in human colorectal cancer. Cancer Res. 69, 4926-4934.

Vihinen, P., Ala-aho, R., and Kahari, V. M. (2005). Matrix metalloproteinases as therapeutic targets in cancer. Curr. Cancer Drug Targets 5 , 203-220.

Wei, X., Prickett, T. D., Viloria, C. G. Molinolo, A., Lin, J. C., CardenasNavia, I., Cruz, P., Rosenberg, S. A., Davies, M. A., Gershenwald, J. E., Lopez-Otin, C., and Samuels, Y. (2010). Mutational and functional analysis reveals ADAMTS18 metalloproteinase as a novel driver in melanoma. Mol. Cancer Res. 8 1513-1525.
Zhou, Z., Apte, S. S., Soininen, R., Cao, R., Baaklini, G. Y., Rauser, R. W., Wang, J., Cao, Y., and Tryggvason, K. (2000). Impaired endochondral ossification and angiogenesis in mice deficient in membranetype matrix metalloproteinase I. Proc. Natl. Acad. Sci. U.S.A. 97, 4052-4057.

Zigrino, P., Kuhn, I., Bauerle, T., Zamek, J., Fox, J. W., Neumann, S., Licht, A., Schorpp-Kistner, M. Angel, P., and Mauch, C. (2009). Stromal expression of MMP-13 is required for melanoma invasion and metastasis. J. Invest. Dermatol. 129, 2686-2693.

Zucker, S., and Cao, J. (2009). Selective matrix metalloproteinase (MMP) inhibitors in cancer therapy: ready for prime time? Cancer Biol. Ther. 8, 2371-2373.

Zucker, S., Pei, D., Cao, J., and LopezOtin, C. (2003). Membrane typematrix metalloproteinases (MTMMP). Curr. Top. Dev. Biol. 54, $1-74$.

Conflict of Interest Statement: The authors declare that the research was conducted in the absence of any commercial or financial relationships that could be construed as a potential conflict of interest.

Received: 08 May 2012; accepted: 27 June 2012; published online: 17 July 2012.

Citation: Noël A, Gutiérrez-Fernández A, Sounni NE, Behrendt N, Maquoi E, Lund $I K$, Cal S, Hoyer-Hansen G and LópezOtín C (2012) New and paradoxical roles of matrix metalloproteinases in the tumor microenvironment. Front. Pharmacol. 3:140. doi: 10.3389/fphar.2012.00140

This article was submitted to Frontiers in Pharmacology of Anti-Cancer Drugs, a specialty of Frontiers in Pharmacology. Copyright (c) 2012 Noël, GutiérrezFernández, Sounni, Behrendt, Maquoi, Lund, Cal, Hoyer-Hansen and LópezOtin. This is an open-access article distributed under the terms of the Creative Commons Attribution License, which permits use, distribution and reproduction in other forums, provided the original authors and source are credited and subject to any copyright notices concerning any third-party graphics etc. 